\title{
ENDOGENOUS CARBON MONOXIDE; WE DON'T KNOW
}

\author{
Sultan Tuna Akgöl Gür ${ }^{1} \odot$, illker Akbaş ${ }^{2} \odot$ \\ ${ }^{1}$ Emergency Physician, Department of Emergency Medicine, Faculty of Medicine, University of Ataturk, Erzurum, Turkey \\ ${ }^{2}$ Department of Emergency Medicine, Bingöl State Hospital, Bingol, Turkey
}

Disaster Emerg Med J 2019; 4(3): 128-129

\section{Endogenous Carbon Monoxide; We Don't Know}

Endogenous Carbon Monoxide (CO) is a gas involved in cell signalling events that are necessary for the regulation of biological systems. However, it leads to impaired efficiency of oxygen storage and transport by haemoglobin $(\mathrm{Hb})$ through $\mathrm{CO}$ protein binding to haem. People breathing air without an environmental CO source will still have measurable levels of circulating $\mathrm{COHb}$ due to both protein catabolism and endogenous $\mathrm{CO}$ production. Endogenous $\mathrm{CO}$ is produced from the oxidative degradation of both proteins by the stress response enzyme haem oxygenase ( $\mathrm{HO})$. $\mathrm{HO}$ acts as a defence mechanism against oxidative stress and is induced by reactive oxygen species. CO production may be affected by various physiological factors, including disease [1]. In normal degradation of $\mathrm{Hb}$, the porphyrin ring of the hem is broken with $\mathrm{HO}$ at the $\alpha$-methine bridge. $\mathrm{HO}$ coexists with NADPH-flavoprotein reductase and biliverdin reductase on the endoplasmic reticulum, where it catabolizes haem, biliverdin, iron and $\mathrm{CO}$ in an $\mathrm{O} 2$ and $\mathrm{NADPH}$-dependent manner. Biliverdin is then separated by biliverdin reductase, bilirubin, a potent endogenous antioxidant [2]. Increased levels of both after erythrocyte destruction, increased endogenous $\mathrm{CO}$ production and increased $\mathrm{COHb}$ levels have been shown $[3,4]$. When haemolysis and abnormal metabolism increase, the $\mathrm{CO}$ production rate in our body can increase significantly [4]. Both are the main site of catabolism and thus the main organ of $\mathrm{CO}$ production in the liver. Following the liver, spleen, brain and erythropoietic systems are organs and systems in which CO production occurs [5]. CO formation rates may be due to high levels of $\mathrm{HO}$ activity in these tissues $[3,4,6]$. Although $\mathrm{CO}$ was previously known only as a toxic gas with high binding properties to haemoglobin, it has now been shown to play an important role in many physiological and pathophysiological processes in the cardiovascular, immune and neurological systems [7]. The physiological effect of $\mathrm{CO}$ occurs as nitric oxide increases the production of cyclic guanylate cyclase (cGMP) as well as increases soluble cGMP [8]. CO, which has antiapoptotic and anti-inflammatory potential, has vasodilatation properties on the cardiovascular system [9]. Although the cytoprotective roles of $\mathrm{CO}$, in vitro studies using CO-releasing molecules, and in vivo studies using high exogenous $\mathrm{CO}$ exposure have been investigated, the behaviour of $\mathrm{CO}$ under pathophysiological conditions is still unknown [10]. While CO levels measured by carboxyhaemoglobin $(\mathrm{COHb})$ have been shown to have high concentrations in smokers, endogenous $\mathrm{CO}$ concentration levels of those with various pathophysiological conditions are uncertain [11]. There are several research articles related to endogenous $\mathrm{COHb}$ and diseases. One of them is the work of Kobayashi et al. Kobayashi et al. Investigated the relationship between endogenous $\mathrm{COHb}$ and ACS and divided them into four groups as non-smoker ACS and non-smoker ACS in 235 patients. As expected, COHb levels were higher in smokers. In this study, it was concluded that endogenous CO may be useful for evaluating the risk of cardiovascular stress [12]. One of the diseases investigated in relation to endogenous $\mathrm{COHb}$ and diseases is pulmonary embolism. Kakavas et al. Investigated $\mathrm{COHb}$ levels and prognosis in patients with pulmonary embolism. This study was retrospectively performed on 156 patients. In univariate logistic regression analysis, $\mathrm{COHb}$ levels were associated with mortality and in multivariate analysis only $\mathrm{COHb}$ was

ADDRESS FOR CORRESPONDENCE:

Ilker Akbaş, Emergency Physician, MD, Department of Emergency Medicine, Bingöl State Hospital, Bingöl Turkey Tel.: 00905444222880, fax: 00904422363133, e-mail: akbasilker@gmail.com

Address: Atatürk Üniversitesi, Tıp Fakültesi, Acil Tıp Anabilim Dalı, Yakutiye, Erzurum 
found to be an independent predictor of in-hospital mortality [13] as a result, endogenous $\mathrm{COHb}$ can still be studied in many diseases.

\section{REFERENCES}

1. Owens EO. Endogenous carbon monoxide production in disease. Clin Biochem. 2010; 43(15): 1183-1188, doi: 10.1016/j.clinbiochem.2010.07.011, indexed in Pubmed: 20655892.

2. Tenhunen R, Marver HS, Schmid R. The enzymatic conversion of heme to bilirubin by microsomal heme oxygenase. Proc Natl Acad Sci U S A. 1968; 61(2): 748-755, doi: 10.1073/pnas.61.2.748, indexed in Pubmed: 4386763.

3. Coburn RF, Williams WJ, Forster RE. Effect of Erythrocyte Destruction on Carbon Monoxide Production in Man. J Clin Invest. 1964; 43: 1098-1103, doi: 10.1172/JCl104994, indexed in Pubmed: 14171787.

4. Coburn RF, Williams WJ, Kahn SB. Endogenous carbon monoxide production in patients with hemolytic anemia. J Clin Invest. 1966; 45(4): 460-468, doi: 10.1172/JCl105360, indexed in Pubmed: 5937023.

5. Berk PD, Blaschke TF, Scharschmidt BF, et al. A new approach to quantitation of the various sources of bilrubin in man. J Lab Clin Med. 1976; 87(5): 767-780, indexed in Pubmed: 1270887.

6. Coburn RF, Blakemore WS, Forster RE. Endogenous carbon monoxide production in man. J Clin Invest. 1963; 42: 1172-1178, doi: 10.1172/ JCl104802, indexed in Pubmed: 14021853.

7. Brouard S, Otterbein LE, Anrather J, et al. Carbon monoxide generated by heme oxygenase 1 suppresses endothelial cell apoptosis.
J Exp Med. 2000; 192(7): 1015-1026, doi: 10.1084/jem.192.7.1015, indexed in Pubmed: 11015442.

8. Furchgott RF, Jothianandan D. Endothelium- dependent and independent vasodilation involving cyclic GMP: relaxation induced by nitric oxide, carbon monoxide and light. Blood Vessels. 1991; 28(1-3): 52-61, indexed in Pubmed: 1848126.

9. Ryter SW, Alam J, Choi AMK. Heme oxygenase-1/carbon monoxide: from basic science to therapeutic applications. Physiol Rev. 2006; 86(2): 583-650, doi: 10.1152/physrev.00011.2005, indexed in Pubmed: 16601269.

10. Stein $A B$, Bolli $R$, Dawn $B$, et al. Carbon monoxide induces a late preconditioning-mimetic cardioprotective and antiapoptotic milieu in the myocardium. J Mol Cell Cardiol. 2012; 52(1): 228-236, doi: 10.1016/j.yjmcc.2011.11.005, indexed in Pubmed: 22119801.

11. Hee J, Callais F, Momas I, et al. Smokers' behaviour and exposure according to cigarette yield and smoking experience. Pharmacol Biochem Behav. 1995; 52(1): 195-203, doi: 10.1016/0091-3057(95)00089-f, indexed in Pubmed: 7501665.

12. Kobayashi A, Mizukami $H$, Sakamoto N, et al. Endogenous carbon monoxide concentration in blood elevates in acute coronary syndrome of nonsmoker population. Fukushima J Med Sci. 2015; 61(1): 72-78, doi: 10.5387/fms.2015-1, indexed in Pubmed: 26135664.

13. Kakavas S, Papanikolaou A, Balis E, et al. Carboxyhemoglobin and methemoglobin levels as prognostic markers in acute pulmonary embolism. Am J Emerg Med. 2015; 33(4): 563-568, doi: 10.1016/j. ajem.2015.01.046, indexed in Pubmed: 25769799. 